EGU21-10259, updated on 11 May 2021

https://doi.org/10.5194/egusphere-egu21-10259

EGU General Assembly 2021

(c) Author(s) 2021. This work is distributed under

the Creative Commons Attribution 4.0 License.

\title{
Investigating bioretention cell performance: A large-scale lysimeter study
}

Daniel Green ${ }^{1}$, Ross Stirling ${ }^{1}$, Simon De Ville ${ }^{2}$, Virginia Stovin ${ }^{2}$, and Richard Dawson ${ }^{1}$

${ }^{1}$ Newcastle University, National Green Infrastructure Facility, School of Engineering, Newcastle University, UK (daniel.green@newcastle.ac.uk)

${ }^{2}$ Department of Civil \& Structural Engineering, University of Sheffield, Sheffield, S1 3JD, UK

Sustainable Drainage Systems (SuDS) are a widely adopted approach for managing excess urban runoff by intercepting, retaining and attenuating the flow of water through the built environment, playing a key role in reducing urban flood risk. Vegetated bioretention cells ('rain gardens') are one of the most simple, practical and commonly implemented SuDS options and can be easily retrofitted into urban spaces to deal with surface water from paved areas. Although current UK and international guidance provides design guidance for SuDS, no quantitative indications on their hydrological performance are currently available. This study aims to provide evidence to assess the effectiveness of such systems to support optimal implementation of vegetated bioretention cells for stormwater management.

Four purpose built, large-scale lysimeter experiments $(2.0 \mathrm{~m} \times 2.0 \mathrm{~m}$, each divided into two isolated $1.0 \mathrm{~m} \times 2.0 \mathrm{~m}$ cell pairs) were designed to provide long-term monitoring data of key hydrological variables and demonstrate the capacity and effectiveness of monitored bioretention systems. The lysimeters were filled with an engineered soil profile consisting of a surface SuDS substrate (700 $\mathrm{mm}$ depth) to sustain vegetation growth and store/attenuate flows, and drainage layers (300 mm depth) consisting of a fine gravel transition layer to prevent the movement of fine sediments and a course gravel base layer to allow free drainage into gauged outflow units.

Each of the lysimeter cells feature a dense sensor network, allowing spatiotemporal soilatmosphere interactions to be observed and changes in relation to rainfall events to be quantified. Tipping bucket rain gauges situated on each of the lysimeters allow the quantification of local precipitation inflows, which are also analysed in the context of site-wide weather monitoring stations to calculate Penman-Monteith reference evapotranspiration. Outflow from the drainage layer of each lysimeter cell is measured using an outflow gauge. Additionally, a network of in-situ soil sensors were deployed throughout the substrate profile at various depths to quantify soil water movement and changes in volumetric water content, soil temperature, electrical conductivity, soil-water potential and hydrostatic water level in accordance with localised 
weather conditions. Quantifying inflows, storages and losses allows an understanding of the lysimeter mass balance. Further, each of the lysimeter cell pairs were planted with different planting styles (unvegetated control, reference short grass and two uniform mono-cropped shrub species) to provide differing reference evapotranspiration scenarios and to understand the influence of vegetation on bioretention cell performance.

This paper outlines the commissioning of a large-scale lysimeter study at the National Green Infrastructure Facility and presents results from mid-2020 onwards, highlighting the hydrological performance of the bioretention cells under a range of natural storm events and climatic conditions. Lysimeter mass balance and retention efficiencies are presented for each of the vegetation scenarios. Further, differences in soil-water retention ability between the lysimeters are examined in relation to the efficiency of various planting styles and their comparative evapotranspirative behaviour. Working together with a range of stakeholders involved in UK SUDS schemes, this work is helping to inform design criteria and anticipated bioretention cell performance using a quantified evidence base. 